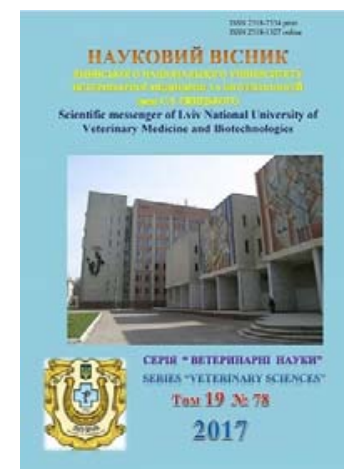

Науковий вісник Львівського національного університету ветеринарної медицини та біотехнологій імені С.З. Гжицького

Scientific Messenger of Lviv National University of Veterinary Medicine and Biotechnologies

doi:10.15421/nvlvet7808

ISSN 2518-7554 print

ISSN 2518-1327 online

http://nvlvet.com.ua/

УДК 602.9:611.018:616-006:636.028

\title{
Особливості клітинного циклу мезенхімальних стовбурових клітин 3 жирової тканини собаки за різних пасажів культивування
}

\author{
Л.В. Кладницька \\ kladlarisa@ukr.net \\ Національний університет біоресурсів і природокористування України \\ вул. Потехіна, 16, м. Київ, 03041, Україна
}

Досліджено особливості перебігу клітинного циклу культури мезенхімальних стовбурових клітин з жирової тканини собаки за різних пасажів культивування.

Мезенхімальні стовбурові клітини отримували з жирової тканини собаки методом експланта у нашій модифікації в умовах ламінарного боксу. Культивування клітин проводили за $37^{\circ} \mathrm{C}, 100 \%$ вологості і $5 \%$ вмісті СО 2 у середовищі культивування Ігла, модифікованого Дюльбекко із додаванням 15\% фетальної сироватки бичків та 1\% антибіотикаантимікотика. Середовище культивування змінювали 2-3 рази на тиждень. Отримували культуру мезенхімальних стовбурових клітин 2-го, 7-го та 12-го пасажів. Методом проточної циитофлуориметрї визначали рівень анеуплоїдї та розподіл клітин за фазами клітинного цчиклу. За допомогою інвертованого мікроскопа Aхіоvert 40 досліджували морфологію клітин різних пасажів.

Досліджено, що культура мезенхімальних стовбурових клітин з жирової тканини на 2-му пасажі містила значну кількість клітин проліферативного пулу $\left(S+G_{2} / M\right)$ і становила 29,51 $\pm 3,56 \%$ від кількості диплоїдних клітин. Кількість анеуплоідних клітин становила 1,55 $\pm 0,43 \%$. Усі клітини мали фібробластоподібну морфологію.

Встановлено, щуо на середніх пасажсах (7-й) у культурі мезенхімальних стовбурових клітин з жирової тканини собаки не виявлено достовірних змін у розподілі клітин за фазами клітинного ичиклу. Кількість диплоїдних клітин проліферативного пулу $G_{2} / M+S$ та пресинтетичного періоду $G_{0} / G_{1}$ залишається без істотних змін. Рівень анеуплоїдї підвишується у межах тендениіі. Морфологічно клітини зберігали фібробластоподібну форму.

За 12-го пасажу культивування визначено достовірне зниження показника кількості клітин проліферативного пулу $\left(S+G_{2} / M\right)$, який становить 18,93 \pm 0,66\% від усісї кількості диплоїдних клітин у порівнянні з 2-м пасажем. Кількість анеуплоїдів достовірно зростає і становить 3,49 \pm 0,38\%. Морфологічно в окремих клітин з'являються відростки. Показник сили впливу пасажування на вміст диплоїдних клітин проліферативного пулу $G_{2} / M+S$ в культурі становить $\eta^{2}{ }_{x}=70 \%$ (при $P<0,05)$. Отже, перші характерні ознаки старіння культури стовбурових клітин з жирової тканини собаки з'являються на 12-му пасажі культивування.

Ключові слова: мезенхімальні стовбурові клітини, жирова тканина, собака, культивування, клітинний цикл, фази, анеуплоїди, диплоїди, проліферативний пул.

\section{Особенности клеточного цикла мезенхимальных ствовловых клеток из жировой ткани собаки на разных пасажах культивирования}

\author{
Л.В. Кладницкая \\ kladlarisa@ukr.net
}

Национальный университет биоресурсов и природопользования Украинь ул. Потехина, 16, г. Киев, 03041, Украина

Citation:

Kladnytska, L.V. (2017). The cell cycle features of canine adipose-derived mesenchymal stem cells on different passages of cultivation. Scientific Messenger LNUVMB, 19(78), 36-40. 
Исследованы особенности клеточного ичкла культуры мезенхимальных стволовых клеток из жировой ткани собаки при различных пассажах культивирования.

Мезенхимальные стволовые клетки получали из жировой ткани собаки методом экспланта в нашей модификации в условиях ламинарного бокса. Культивирование клеток проводили при $37{ }^{\circ} \mathrm{C}, 100 \%$ влажности и $5 \%$ содержании СО в среде культивирования Игла, модифицированной Дюльбекко (DМЕМ) с добавлением 15\% фетальной сыворотки бычков и 1\% антибиотика-антимикотика. Среду культивирования меняли 2-3 раза в неделю. Получали культуру мезенхимальньх стволовых клеток 2-го, 7-го и 12-го пассажей. Методом проточной циттофлуориметрии определяли уровень анеуплоидии и распределение клеток по фазам клеточного цикла. С помощью инвертированного микроскопа Ахіоуегt 40 исследовали морфологию клеток различных пассажей.

Доказано, что культура мезенхимальных стволовых клеток из жировой ткани на 2-ом пассаже содержит значительное количество клеток пролиферативного пула $\left(S+G_{2} / M\right)$ и составляет 29,51 $\pm 3,56 \%$ диплоидных клеток. Количество анеуплоидных клеток составляет 1,55 \pm 0,43\%. Все клетки имели фибробластоподобную морфологию.

Установлено, что на средних пассажах (7-й) в культуре мезенхимальных стволовых клеток из жировой ткани собаки не выявлено достоверных изменений в делении клеток по фазам клеточного ичила. Количество диплоидных клеток пролиферативного пула $G_{2} / M+S$ и пресинтетического периода $G_{0} / G_{1}$ остается без существенных изменений. Уровень анеуплоидии повышается в пределах тенденции. Морфологически клетки сохраняют фибробластоподобную форму.

На 12-ом пассаже культивирования выявлено достоверное снижение показателя количества клеток пролиферативного пула $\left(S+G_{2} / M\right)$, который составляет $18,93 \pm 0,66 \%$ от всего количества диплоидных клеток по сравнению со 2-м пассажем. Количество анеуплоидных клеток достоверно повышается и составляет 3,49 \pm 0,38\%. Морфологически в отдельных клетках появляются отростки. Показатель силь воздействия культивирования на содержание диплоидных клеток пролиферативного пула $\left(S+G_{2} / M\right)$ в культуре составляет $\eta^{2} x=70 \%(P<0,05)$. Итак, первье характернье признаки старения культуры мезенхимальных стволовых клеток из жировой ткани собаки появляются на 12-ом пассаже культивирования.

Ключевые слова: мезенхимальные стволовые клетки, жировая ткань, собака, культивирование, клеточный цуикл, фазы, анеуплоиды, диплоиди, пролиферативный пул.

\title{
The cell cycle features of canine adipose-derived mesenchymal stem cells on different passages of cultivation
}

\author{
L.V. Kladnytska \\ kladlarisa@ukr.net \\ National University of Life and Environmental Sciences of Ukraine \\ Potekhina Str., 16, Kyiv, 03041, Ukraine
}

The features of the cell cycle of culture of adipose-derived mesenchymal stem cells from the for different cultivating passages were studied.

Mesenchymal stem cells were obtained from the adipose tissue of the dog under a laminar flow hood by an explant method in our modification. Cell cultivation was carried out at $37{ }^{\circ} \mathrm{C}, 100 \%$ moisture and $5 \% \mathrm{CO}_{2}$ in Dulbecco's modified Eagle's medium (DMEM) containing 10\% fetal bovine serum (FBS) and 1\% antibiotic-antimycotic. The culture medium was changed 2-3 times per week and the cells were selected by their capacity to attach to the flask surface. When culture flasks became $80 \%$ confluence, cells were detached with $0.25 \%$ trypsin containing $1 \mathrm{mmol} / \mathrm{L}$ EDTA and subsequently replayed at a concentration of $10^{4} \mathrm{cells} / \mathrm{cm}^{2}$ for next passaging. A cells culture of adipose derived mesenchymal stem cells was obtained on the 2nd, 7th and 12th passages. The method of flow cytometry determined the level of aneuploid cells and the distribution in the cell cycle phases. The morphology of cells of different passages was studied using an inverted microscope Axiovert 40.

It was investigated that the culture of mesenchymal stem cells from adipose tissue in the 2nd passage contains a significant number of the proliferative pool $\left(S+G_{2} / M\right)$ cells and it was $29.51 \pm 3.56 \%$ of the total number of diploid cells. The number of aneuploid cells was $1.55 \pm 0.43 \%$. All cells had fibroblast-like morphology.

It was established that in the middle passages (7th) in the culture of mesenchymal stem cells from the adipose tissue of the dog no significant changes were found in the distribution of cells in the phases of the cell cycle. The number of diploid cells of the proliferative pool $S+G_{2} / M$ and the $G_{0} / G_{1}$ pre-synthetic period remains unchanged. The level of aneuploidy increases only within the tendency. Morphologically, cells had fibroblast-like form.

It was determined on 12th passage of cultivation, a significant decrease in the number of cells of the proliferative pool $(S+G 2 / M)$, which was $18.93 \pm 0.66 \%$ of the total number of diploid cells compared to the 2nd passage. The number of aneuploid cells increased and it was $3.49 \pm 0.38 \%$. Morphologically, separate cells had processes.

The indicator of the effect of cells cultivation on the content of diploid cells of the proliferative pool $\left(S+G_{2} / M\right)$ in culture is $\eta^{2} x=$ $70 \%(P<0.05)$. So, first characteristic properties of the aging of the culture of canine adipose-derived mesenchymal stem cells appear on the 12th passage of cultivation.

Key words: mesenchymal stem cells, adipose tissue, dog, cultivation, cell cycle, phases, aneuploids, diploid, proliferative pool.

\section{Вступ}

Корекція фізіологічних функцій та відновлювальна терапія за патологічних станів за допомогою стовбурових клітин має все більше застосування у гуманній та ветеринарній медицині (Haghighat et al., 2011; Volk and Theoret, 2013; Marx et al., 2014; Arnhold and
Wenisch, 2015; Kathrine et al., 2017). Окремі автори наголошують на відмінностях біологічних властивостей мезенхімальних стовбурових клітин, отриманих 3 різних джерел, зокрема кісткового мозку, жирової тканини (Dmitrieva et al., 2011; Reich et al., 2012). Zhang Z.X. та інші (Zhang et al., 2007). При дослідженні культури мезенхімальних стовбурових клітин 
3 кісткового мозку людини на 1-му та 3-му пасажах взагалі не виявили анеуплоїдних, поліплоідних клітин та порушень хромосомного апарату. При дослідженні МСК 3 жирової тканини макак резус виявили появу анеуплоідних клітин після першого пасажу, це була резус-хромосома, яка після першого пасажу мала тетраплоїдний каріотип. Ці результати вказують на те, що довгострокове культивування МСК призводить до значних змін у кінетиці клітинного циклу що засвідчує необхідність його відстеження перед клінічним застосуванням (Zhang et al., 2007). Для якісного надання послуг необхідно оцінювати біологічні властивості культури клітин, яка застосовується для трансплантації. При тривалому культивуванні відбуваються зміни проліферативної активності клітин, з'являються зміни в хромосомах, і як наслідок, біологічне старіння культури. Дослідження клітинного циклу культури забезпечує визначення особливостей клітин культури за різних пасажів культивування. Дані щодо біологічних властивостей культури мезенхімальних стовбурових клітин собак, отриманих з різних джерел, у сучасній літературі обмежені. Отже, визначення особливостей клітинного циклу мезенхімальних стовбурових клітин $з$ жирової тканини собаки за різних пасажів культивування $є$ актуальним питанням.

\section{Матеріал і методи досліджень}

Досліди проводили на собаках різних порід віком до 12-ти місяців. Всі дослідження на тваринах були проведені відповідно до Правил належної лабораторної практики щодо використання експериментальних тварин та з дотриманням закону України «Про захист тварин від жорстокого поводження».

Для отримання МСК з жирової тканини застосовували метод експланта у нашій модифікації (Kladnytska et al., 2016). Культивування клітин проводили за $37{ }^{\circ} \mathrm{C}, 100 \%$ вологості і $5 \%$ вмісті $\mathrm{CO}_{2}$ у середовищі культивування Ігла, модифікованого Дюльбекко із додаванням 15\% фетальної сироватки бичків та 1\% антибіотика-антимікотика. Середовище культивування змінювали 2-3 рази на тиждень. Отримували культуру мезенхімальних стовбурових клітин 2-го, 7-го та 12-го пасажів, проводили дослідження рівня анеуплоїдії, розподіл клітин за фазами клітинного циклу методом проточної цитофлуориметрії (Nicoletti et al., 1991) та визначали морфологію клітин. До осаду клітин різних пасажів у кількості $1 \times 10^{6}$ на пробу додавали 300 мкл Тритон X-100, який забезпечує руйнування клітинної мембрани, 200 мкл фосфатнобуферного розчину, 10 мкл рибонуклеази, яка розділяє нитки ДНК, та 15 мкл РІ (пропідій іодіду), що вибірково зв'язується 3 ДНК (усі реагенти фірми «Sigma Chemical Co», USA). Після обережного струшування компоненти нуклеарної суспензії інкубували за $22-25{ }^{\circ} \mathrm{C}$ впродовж 30 хв у темряві. Для оцінки дольового вмісту клітин в основних фазах клітинного циклу $\left(\mathrm{G}_{0} / \mathrm{G}_{1}, \mathrm{~S}, \mathrm{G}_{2}+\mathrm{M}\right)$ гістограми розподілу обробляли за допомогою спеціалізованої математичної програми Mod Fit LT 2.0 (BDIS, CША) для комп'ютерів Macintosh. Реєстрацію даних виконували на проточному цитометрі FACS Calibur («Becton
Dickinson», США) із застосуванням вузькосмужкового фільтра 585/42 нм для вимірювання флуоресценції PI. 3 кожного зразка нуклеарної суспензії аналізу підлягало 10000 подій. Визначали показники: кількість диплоїдних і анеуплоідних клітин у зразках, розподіл клітин кожної популяції за фазами клітинного циклу $\mathrm{G}_{0} / \mathrm{G}_{1}, \mathrm{~S}, \mathrm{G}_{2} / \mathrm{M}$.

Для дослідження кількісних результатів дослідження визначали значення середнього (M) і помилку середнього (m). Для порівняння середніх показників досліджуваних груп визначали параметричний tкритерій Стьюдента, здійснювали одно факторний дисперсійний аналіз.

\section{Результати та їх обговорення}

Для отримання МСК $з$ жирової тканини собак застосовували методику експланта у нашій модифікації. Матеріалом експланта слугував абдомінальний жир собак віком до 12-ти місяців, який відбирали у стерильних умовах під час виконання планових операцій. Жирову тканину тричі промивали фосфатнобуферним розчином і переносили у інший стерильний посуд. Первинний матеріал піддавали механічній дезагрегації і розміщували у культуральних чашках. У культуральний посуд вносили середовище для культивування DMEM, 15\% фетальної сироватки бичків (FBS), 1\% антибіотика-антимікотика. Культуральні чашки 3 експлантом абдомінальної жирової тканини культивували за стандартних умов у $\mathrm{CO}_{2}$ інкубаторі за температури $37^{\circ} \mathrm{C}$.

Морфологічно клітини 2-го пасажу мали фібробластоподібну морфологію, культура клітин була однорідною. На 7-му пасажі фібробластоподібна морфологія клітин залишалась сталою. На 12-му пасажі окремі клітини культури набували морфологічних змін - в них з'являлися додаткові відростки.

Аналіз показників, отриманих за проточної цитометрії дав можливість оцінити розподіл клітин культур за різних пасажів за фазами клітинного циклу, оцінити їх рівень генетичної стабільності. Встановлено, що за умов культивування відбувалися вірогідні зміни у розподілі популяції клітин на диплоїдні та анеуплоїдні, а також за фазами клітинного циклу.

Ранні пасажі культури МСК з жирової тканини характеризуються високим вмістом диплоїдних клітин, кількість яких становить на 2-му пасажі 98,45 \pm 0,39\% (табл. 1). Рівень анеуплоідних клітин на 2-му пасажі низький із показником 1,55 $\pm 0,43 \%$ (табл. 2). Це засвідчує сталість каріотипу клітин, що культивуються на ранніх пасажах. Серед диплоїдних клітин за розподілом за фазами клітинного циклу ми бачимо високий показник проліферативного пулу $\mathrm{G}_{2} / \mathrm{M}+\mathrm{S}$, який становить $25,51+3,56 \%$ (табл. 1 ).

Пресинтетичний період $\mathrm{G}_{0} / \mathrm{G}_{1}$ характеризується перевагою анаболічних процесів у клітинах, які забезпечують збільшення маси після поділу, анатомічне та функціональне відновлення органел, збільшення каріолеми, посилення процесів транскрипції, трансляції, синтезу тригерних білків, активаторів $\mathrm{S}$ фази клітинного циклу. 
Табличя 1

Вміст диплоїдів та розподіл мезенхімальних стовбурових клітин з жирової тканини за фазами клітинного циклу за різних пасажів культивування, \% $\mathbf{M} \pm \mathbf{m}(\mathbf{n}=\mathbf{3})$

\begin{tabular}{|l|c|c|c|c|c|}
\hline Пасаж & Вміст диплоїдів & $\mathrm{G}_{0} / \mathrm{G}_{1}$ & $\mathrm{~S}$ & $\mathrm{G}_{2} / \mathrm{M}$ & $\mathrm{G}_{2} / \mathrm{M}+\mathrm{S}$ \\
\hline 2 -й & $98,45 \pm 0,39$ & $70,49 \pm 3,17$ & $20,58 \pm 1,94$ & $8,93 \pm 1,63$ & $29,51 \pm 3,56$ \\
\hline 7 -й & $98,28 \pm 0,56$ & $73,52 \pm 5,01$ & $17,43 \pm 0,91$ & $9,05 \pm 1,16$ & $26,15 \pm 0,29$ \\
\hline 12 -й & $96,51 \pm 0,38^{*}$ & $81,07 \pm 0,61^{*}$ & $13,42 \pm 0,82^{*}$ & $5,51 \pm 0,52$ & $18,93 \pm 0,66^{*}$ \\
\hline
\end{tabular}

Примітка: * - $\mathrm{P}<0,05$ - порівняно 3 показниками 2-го пасажу.

Завдяки цим білкам клітина проходить точку рест- залишається на тому самому рівні, а також розподіл рикції $\mathrm{R}$ і спрямовується у $\mathrm{S}$ період. Вміст диплоїдних клітин у $\mathrm{G}_{0} / \mathrm{G}_{1}$ фазі становить $70,49 \pm 3,17 \%$.

Серед анеуплоїдів у $\mathrm{G}_{0} / \mathrm{G}_{1}$ фазі зареєстровано $87,35 \pm 1,29$, а показник проліферативного пулу $\mathrm{G}_{2} / \mathrm{M}+\mathrm{S}$ становить $12,65 \pm 1,02 \%$ (табл. 2). Такі дані вказують на затримку анеуплоїдних клітин у фазі репродуктивного спокою $\mathrm{G}_{0}$

На 7-му пасажі культивування МСК 3 жирової тканини ми бачимо,що кількість диплоїдних клітин клітин за фазами клітинного циклу не має достовірних змін. Отримані дані дають підставу зробити висновок, що у культурі клітин з жирової тканини на 7му пасажі не з'являються ознаки змін, пов'язаних 3 біологічним віком клітин та впливу на них реагентів під час культивування. Тобто зберігаються всі ознаки якісної культури клітин і їі можна застосовувати для трансплантації.

Табличя 2

Рівень анеуплоїдів та розподіл мезенхімальних стовбурових клітин з жирової тканини за фазами клітинного циклу за різних пасажів культивування, \% M \pm m $(\mathbf{n}=3)$

\begin{tabular}{|l|c|c|c|c|c|}
\hline Пасаж & Вміст клітин & $\mathrm{G}_{0} / \mathrm{G}_{1}$ & $\mathrm{~S}$ & $\mathrm{G}_{2} / \mathrm{M}$ & $\mathrm{G}_{2} / \mathrm{M}+\mathrm{S}$ \\
\hline 2 -й & $1,55 \pm 0,43$ & $87,35 \pm 1,29$ & $8,74 \pm 0,47$ & $3,91 \pm 0,58$ & $12,65 \pm 1,02$ \\
\hline 7 -й & $1,72 \pm 0,19$ & $86,37 \pm 0,93$ & $8,12 \pm 0,72$ & $5,43 \pm 0,57$ & $13,55 \pm 0,31$ \\
\hline 12 -й & $3,49 \pm 0,38^{*}$ & $88,31 \pm 0,69$ & $9,43 \pm 0,62$ & $2,26 \pm 0,18$ & $11,69 \pm 1,12$ \\
\hline
\end{tabular}

Примітка: * - P $<0,05$ - порівняно з показниками 2-го пасажу.

Зовсім іншу картину ми бачимо на 12-му пасажі культивування. Вміст диплоїдних клітин в культурі залишається на високому рівні, але достовірно зменшується від такого на 2-му пасажі культивування. Фаза спокою $\mathrm{G}_{0} / \mathrm{G}_{1}$ характеризується достовірним підвищенням показника вмісту клітин на 10,58\%. $\mathrm{S}$ фаза реплікації ДНК та синтезу гістонів за 12-го пасажу характеризується достовірним зниженням показника кількості диплоїдних клітин на 7,38\% порівняно з 2-им пасажем.

Вміст диплоїдних клітин премітотичної і мітотичної фази $\mathrm{G}_{2} / \mathrm{M}$ на 12-му пасажі зменшується на $3,42 \%$ у межах тенденції, що характеризує зниження проліферативної активності культури. За дисперсійним аналізом кількість пасажів чинить сильний вплив на вміст клітин проліферативного пулу $\mathrm{G}_{2} / \mathrm{M}+\mathrm{S}$ у культурі. Показник сили впливу пасажування на вміст клітин проліферативного пулу $\mathrm{G} 2 / \mathrm{M}+\mathrm{S}$ в культурі становить $\eta_{x}^{2}=70 \%$ (при $\left.\mathrm{P}<0,05\right)$.

Кількість анеуплоїдних клітин достовірно зростає до $3,49 \pm 0,38 \%$. Серед анеуплоїдних клітин 12-го пасажу, загальна кількість яких зростає в процесі культивування, вміст клітин $\mathrm{G}_{0} / \mathrm{G}_{1}$ пулу підвищується в межах тенденції. Вміст клітин проліферативного пулу $\mathrm{G}_{2} / \mathrm{M}+\mathrm{S}$, навпаки, знижується в межах тенденції. На нашу думку це пов'язано 3 обмеженням нерегульованого розмноження клітин завдяки дії стимулюючого фактора на рівні точки рестрикції $\mathrm{R}$ при переході клітин 3 фази спокою $\mathrm{G}_{0} / \mathrm{G}_{1}$ до $\mathrm{S}$ періоду.

Отже, ми бачимо що на 12-му пасажі культивування культури МСК 3 жирової тканини з'являються перші ознаки зміни біологічного стану клітин, які необхідно враховувати при трансплантації.

\section{Висновки}

1. Дослідження клітинного циклу мезенхімальних стовбурових клітин $з$ жирової тканини собаки за різних пасажів культивування $є$ індикатором біологічного стану культури.

2. Ранні пасажі МСК з жирової тканини характеризуються фібробластоподібною морфологією, високим вмістом диплоїдних клітин проліферативного пулу $\mathrm{G}_{2} / \mathrm{M}+\mathrm{S}$, низьким рівнем анеуплоїдії.

3. Клітини культури 7-го пасажу зберігають фібробластоподібну морфологію і не зазнають достовірних змін у розподілі за фазами клітинного циклу та рівнем анеуплоїдії, що засвідчує збереження біологічних властивостей культури.

4. У культурі мезенхімальних стовбурових клітин 3 жирової тканини 12-го пасажу реєструються біологічні зміни - перші ознаки реплікативного старіння. Культура характеризується високим вмістом клітин проліферативного пулу $\mathrm{G}_{2} / \mathrm{M}+\mathrm{S}$, але достовірно нижчим від такого 2-го пасажу і становить 18,93 \pm 0,66\% усіх диплоїдних клітин. Кількість анеуплоїдів достовірно підвищується і становить $3,49 \pm 0,38 \%$. Фаза спокою $\mathrm{G}_{0} / \mathrm{G}_{1}$ характеризується достовірним збільшенням кількості диплоїдних клітин до 81,07 \pm 0,61\%.

5. Показник сили впливу процесу культивування на вміст диплоїдних клітин проліферативного пулу $\mathrm{G}_{2} / \mathrm{M}+\mathrm{S}$ в культурі становить $\eta_{\mathrm{x}}^{2}=70 \%$ (при $\left.\mathrm{P}<0,05\right)$.

Перспективи подальших досліджень будуть спрямовані на визначення особливостей клітинного циклу культури мезенхімальних стовбурових клітин 3 кісткового мозку собак за різних пасажів культивування. 


\section{Бібліографічні посилання}

Marx, C., Silveira, M.D., Selbach, I., da Silva, A.S., Braga, L.M., Camassola, M., Nardi, N.B. (2014). Acupoint injection of autologous stromal vascular fraction and allogeneic adipose-derived stem cells to treat hip dysplasia in dogs. Stem Cells. 2014:391274.

Haghighat, A., Akhavan, A., Hashemi-Beni, B., Deihimi, P., Yadegari, A. (2011). Adipose derived stem cells for treatment of mandibular bone defects: An autologous study in dogs. Dent. Res. J. 8(1), 1-7.

Volk, S., Theoret, C. (2013). Translating stem cell therapies: the role of companion animals in regenerative medicine. Wound Repair Regen. 3, 382-394.

Kathrine, K.J., Christian, G., Jensen, D.H., FischerNielsen, A., Hjuler, T., von Buchwald, C. (2017). Mesenchymal stem cell therapy for laryngotracheal stenosis: A systematic review of preclinical studies. $\begin{array}{lllll}\text { PLOS } & \text { ONE } & 21 & \text { Sep } & 2017\end{array}$ https://doi.org/10.1371/journal.pone.0185283

Arnhold, S., Wenisch, S. (2015). Adipose tissue derived mesenchymal stem cells for musculoskeletal repair in veterinary medicine. Am. J. Stem Cells. 4(1), 1-12.

Reich, C., Raabe, O., Wenisch, S., Bridger, P., Kramer, M., Arnhold, S. (2012). Isolation, culture and chondrogenic differentiation of canine adipose tissue- and bone marrow-derived mesenchymal stem cells a comparative study. Vet. Res. Commun. 2, 139-148.

Dmitrieva, R.I., Minullina, I.R., Bilibina, A.A., Tarasova, O.V., Anisimov, S.V., Zaritskey, A.Y. (2011). Bone marrow- and subcutaneous adipose tissue-derived mesenchymal stem cells: Differences and similarities. Cell Cycle. 11(2), 377-383.

Zhang, Z.X., Guan, L.X., Zhang, K., Wang, S., Cao, P.C., Wang, Y.H., Wang, Z., Dai, L.J. (2007). Cytogenetic analysis of human bone marrow-derived mesenchymal stem cells passaged in vitro. Cell Biol. Int. 31(6), 64, 5-8.

Kladnytska, L.V., Mazurkevych, A.Y., Velychko, S.V., Zhyhunova, O.V. (2016). Otrymannia kultury stovburovykh klityn iz zhyrovoi tkanyny sobaky. Visnyk Sumskoho natsionalnoho ahrarnoho universytetu. Seriia «Veterynarna medytsyna». 6(38), 19-24 (in Ukrainian).

Kladnytska, L.V., Mazurkevych, A.I., Velychko, S.V. (2016). Patent Ukrainy na korysnu model №109148.Sposib otrymannia mezenkhimalnykh stovburovykh klityn iz zhyrovoi tkanyny sobaky; zaiavnyk i vlasnyk Natsionalnyi universytet bioresursiv i pryrodokorystuvannia Ukrainy. № u201602329; zaiavl. 11.03.2016; opubl. 10.08.2016, Biul. № 15 (in Ukrainian).

Nicoletti, I., Migliorati, G., Pagliacci, M.C. (1991). A rapid and simple method for measuring thymocyte apoptosis by propidium iodide staining and flow cytometry. J. Immunol. Methods. 139(2), 271-280.

Received 5.09.2017

Received in revised form 26.09.2017 Accepted 2.10.2017 